\title{
Geomorphological investigations on landslide dams
}

\author{
Carlo Tacconi Stefanelli ${ }^{*}$, Filippo Catani and Nicola Casagli
}

\begin{abstract}
Background: The study of past landslide dams and their consequences has gained a considerable significance for forecasting induced hydraulic risk on people and property.

Landslide dams are rather frequent in Italy, where a broad climatic, geological and morphological variability characterize different part of the peninsula, and have already been studied in literature, focusing different geographical regions with different levels of detail. In order to develop specific tools to assess the landslide dam formation and stability, the first step is to realize a large data archive including a big number of data, collected with a consistent methodology to standardize the quality.

Description: For this reason, this paper reports the results of an extensive bibliographic work and geomorphologic investigation on landslide dams that lead to the development of the wider systematic inventory in Italy. Through the revision and the update of scientific works and historical reports, three hundreds of landslide dams from the Alps to the Southern Apennine and Sicily were identified. During investigations and through cartographic and aerial photos interpretation, several geomorphic parameters of the landslide, the dam body, the valley and the lake, if any, have been determined, or estimated using historical and bibliographical documents analysis.

Conclusions: The collected data were resumed in a database, formed by 57 information fields easy to collect and measure to privilege intuitive usability and future implementation. In order to describe the characteristics of landslide dams in Italy some specific analysis on the different types of landslide movements and their volume, the dam longevity, the main triggers and their geographical distribution were carried out.
\end{abstract}

Keywords: Landslide dam; Database; Geomorphology; Morphometric parameters; Photointerpretation; Italy

\section{Background}

The term "landslide dam" identifies "the natural blockages of river channels caused by slope movements" (Canuti et al., 1998). The riverbed obstruction can be complete or partial. In the first case, the dammed lake would be formed upstream. This causes a serious hazard for the involved river section and for the surrounding areas for kilometers, both upstream and downstream. In upstream areas, rising waters, blocked by the dam, can flood areas over kilometers, causing damage to properties, communication lines and infrastructures. In downstream areas, landslide dam collapse leads to catastrophic events, such as anomalous destructive flood waves. Given that most of the human activity and main infrastructures

\footnotetext{
* Correspondence: tacconi.carlo@gmail.com

Department of Earth Sciences, University of Firenze, Via La Pira, 4, Florence 50121, Italy
}

are located in valley floors, consequences can be dramatic, especially in countries with high population density in mountain areas, such as Italy. Sometimes these situations can be controlled through properly sized engineering works. When this is not possible, for lack of knowledge on the natural event and for technical limitations (related to available time and to size of the phenomenon), landslide dams may represent big hazards. The ability to evaluate the stability and the obstruction likelihood of a dam is therefore crucial. For these reasons, the study of landslide dams and their consequences has acquired a significant relevance in scientific research for prediction and prevention of flood risk on lives and properties (Canuti et al., 1998; Ermini and Casagli, 2003; Dal Sasso et al., 2014).

Some authors have already setup archives of landslide dams for some countries in the world. These include the archive for New Zealand (Korup, 2004), which consists of

\section{Springer}


232 dams, the Swiss database (Bonnard et al., 2011), with 31 cases and the Chinese one, which has even 1239 cases (Peng and Zhang, 2012) and a database of a single regional triggering event with 828 cases during the earthquake of May 12, 2008, in Wenchuan (Fan et al., 2012a,b,c).

Landslide dams are rather frequent in Italy, a country characterized by a broad climatic, geological and morphological variability. Nevertheless, their scientific study has only started after the Val Pola event in 1987 (Sondrio, Northern Italy), when a huge landslide threatened for months the survival of an entire valley. After such an impressive episode, the research on this topic received greater attention and a strong boost. Some authors conducted inventories of regional and inter regional areas (Pirocchi, 1991; Canuti et al., 1998; Ermini, 2000; Pacino, 2002; Coico et al., 2013), with different standards and detail. This heterogeneity of archives, with different scales and level of detail, imposed the need for a single database with national scale that would gather the larger number of known cases all over the Italian territory.

The main aims of this work is to develop a database that includes the largest number of landslide dam events, collected with a similar method to standardize data quality. The geomorphologic investigation on landslide dam events in Italy resulted in the widest systematic inventory, from the Alps to the Southern Apennines and Sicily.

A landslide dam, even when it does not evolve in a catastrophic way, may damage the socio-economic structure of entire valley. The losses are often substantial and are of two categories: direct ones, e.g.: safety measures and infrastructure rebuilding; and indirect ones, more difficult to estimate, e.g.: damage caused to industrial productivity or loss in real estate value.

According to some authors (Swanson et al.; 1986; Canuti et al., 1998; Ermini and Casagli, 2003; Korup, 2004; Dal Sasso et al., 2014), landslide dam behavior can be forecasted and its consequences predicted through geomorphological indexes. Said indexes are comprised of variables identifying the landslide (or the dam) and the river involved. The knowledge of these events is, however, far from complete, since there are many contributing factors in determining their development and behavior over time.

Geomorphologic parameters are usually determined through cartographic and aerial photos interpretation, or estimated via historic and bibliographic documents analysis. The data are gathered into a database, with easy-to-collect information, for an intuitive usability and future implementation. The proper characterization of the phenomenon, through careful study of past events, is the first and main step to develop tools to assess landslide dam formation and stability.

Well documented studies about landslides causing blockage of riverbeds, often with catastrophic consequences, are frequent. Otherwise, those phenomena that had no impact on the urban and infrastructure fabric, or lie outside the historical age, have usually been neglected so that the inventories of landslide dams are usually based on high-impact events.

Landslide dam reports are known since the eighteenth century, like the works of Ruberti (1787), Boccia (1804), Mercanti (1859), Almagià (1907). In more recent times they were studied by Lee and Duncan (1975), Nishizawa and Chiba (1979), Evans (1984, 1986), Schuster (1985), Soldati and Tosatti (1993), Casagli et al. (1995), Carotta (1997), Irmler et al. (2006), Cencetti et al. (2011), Savelli et al. (2012, 2013).

Landslide dams commonly occur in narrow valleys (Fan et al., 2012c), bounded by steep sheer rock walls and by uneven mountains where the mass in motion does not have space to disperse itself. In these places, even modest volumes of displaced material can cause the formation of landslide dams. This is a typical scenario in active geological areas, characterized by volcanic activities, seismic events or post-glacial detensioning. In these environments large amounts of material, such as fractured or weathered rocks, are easily involved in landslide events.

In this paper we present a new integrated landslide dams database for Italy, built on preceding studies merged with new information and statistics.

\section{Construction and content}

In Italy some archives have already been compiled and include information about the dams occurred in specific regional or interregional geographic areas. The most important and complete studies used to compile this final database are: the work by Pirocchi (1992) in the Northern Apennine; the inventory by Ermini (2000) in the central and northern Apennines; the database of Pacino (2002), concerning Sicily. Each of them reports a large number of fully described and morphologically characterized natural dams for their area of study.

Those databases have been extensively revised, checking each case, updating, correcting and completing them with the missing information with specific investigations. An extensive research led to the updating of the databases, both with new cases of damming occurred in each area after their publication and with episodes that were not considered before by the authors.

A careful literature review sometimes allowed to gather more information relating to possible past damming cases and the formation of a lake basin. The research was focused on damming occurred during historical times. For these events, information and relevant contemporary chronicles are more easily available related to important events and in such cases it is easier to correctly reconstruct the sequence of the events. Some cases occurring in the prehistoric age were collected as well, if radiocarbon dating was available (e.g. the case of S. Martino di Castrozza, ID 179, in Siror 
Municipality, or Sutrio, ID 191, in Alta Terme Municipality), or when the event was preserved to such an extent as to guess its nature and to reconstruct its evolution (Fig. 1).

In order to collect new data, the bibliographic research was not limited to the reconstruction of historical chronicles, where the events describing the formation and evolution of a landslide dams are reported, but also involved the whole scientific, geological and geomorphological information of the area where the landslide occurred.

Historical chronicles and scientific and social texts were consulted and we found newspaper to be very useful in particular, because they often reported events with great detail. During the days immediately following the event, plenty of news and information can be found, accompanied by pictures taken just after the event and later. With the availability of all issues of newspapers reporting the event, it is usually possible to collect information to be stored in the database with an acceptable degree of accuracy.

After the collection, the information that allowed the detection and identification of an obstruction case was further completed with various direct or indirect survey techniques.
A geomorphological investigation, through photointerpretation and mapping analysis, was carried out for all cases. It allowed us to collect most of the morphometric parameters for the landslide characterization. An interpretation of stereoscopic aerial photos, dating back since '50s with approximate scales between 1:10.000 and 1:30.000, and a cartographic analysis of maps, with scales between 1:5.000 and 1:10.000, were performed to identify landslide boundaries, lake basins and dam's remnants. Internet tools such as Google Earth were very useful in this phase, especially for dams occurred in more recent times, as for the case of the Scascoli landslide reactivation (ID 72), near Bologna (Fig. 2). This tool, combined with the $3 \mathrm{D}$ view of the ground, allowed, through the comparison of images acquired in different times, to understand and reconstruct the evolution of several landslide dams (such as e.g. as the Costantino lake silting, ID 97, in Reggio Calabria, Southern Italy, showed in Fig. 3) and its consequences on the upstream and downstream area.

The census work has led to the acquisition of 300 documented cases, filed from sources very different for the quantity and quality of the information provided (see

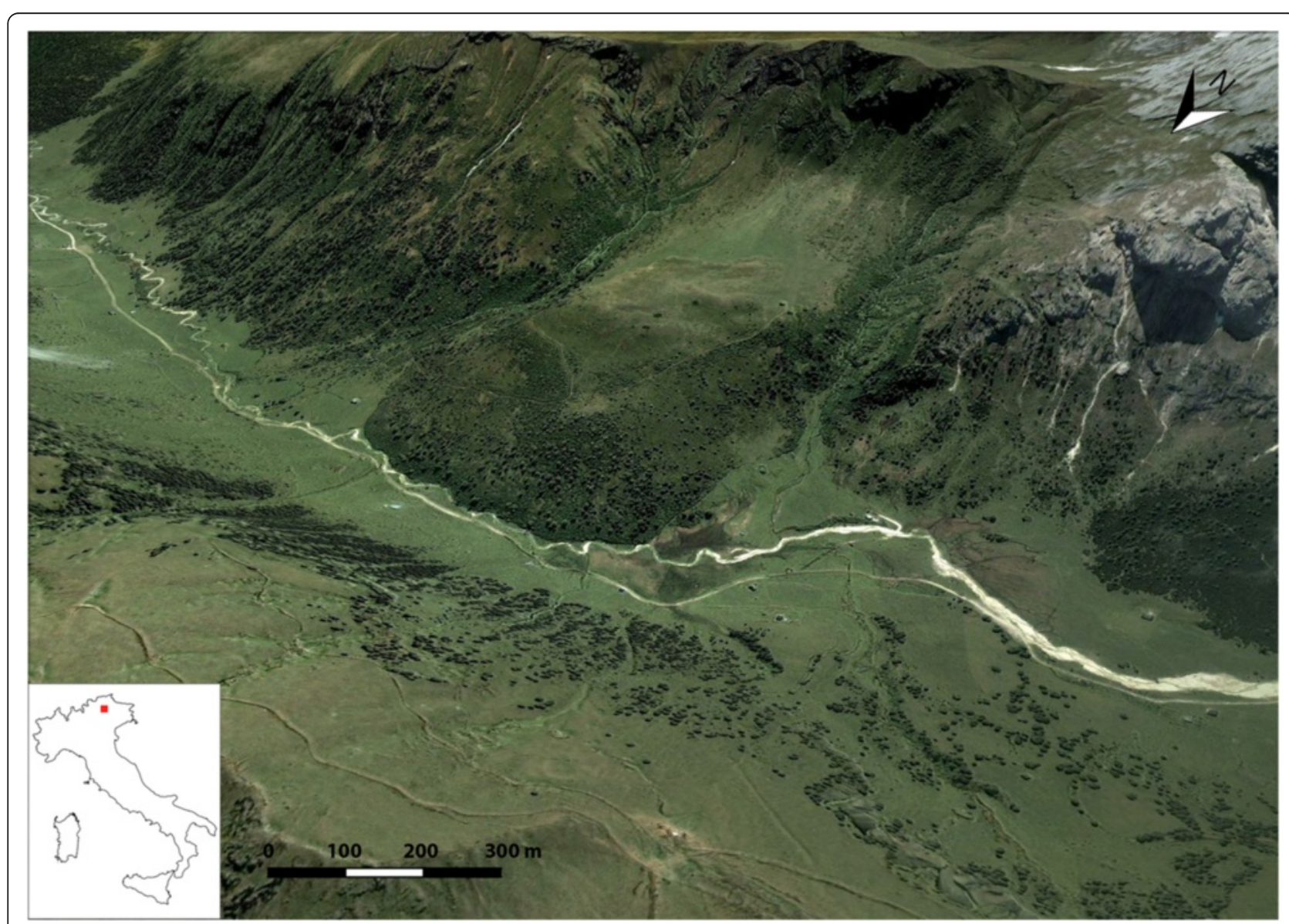

Fig. 1 Actual view of the well preserved prehistoric landslide of Campo di Grevena (ID 177), Trento, Northern Italy (picture from GoogleEarth). Despite the volume (10 Million $\mathrm{m}^{3}$ ) the landslide caused just a partial damming and a river deviation 


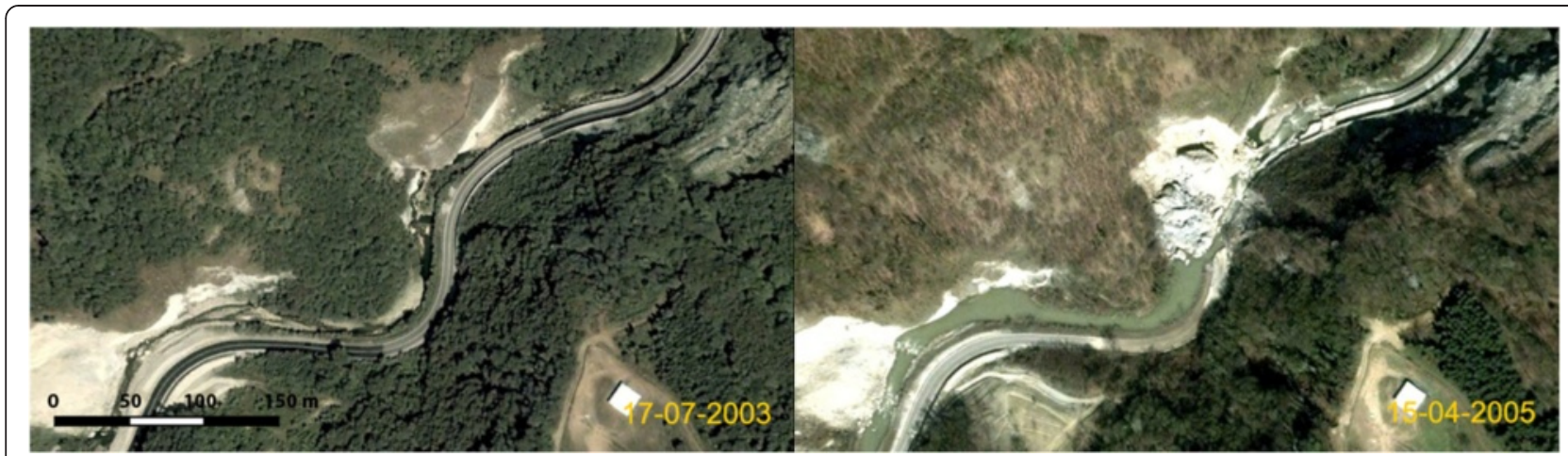

Fig. 2 The Scascoli case (ID 72), Bologna, before and after the landslide reactivation (pictures from GoogleEarth)

Additional file 1). The landslide dams, resulting from the research, were geo-referenced and collected in a GIS database. The Fig. 4 shows the present state of the distribution of Italian landslide dams according to our inventory. The database is obviously an ongoing project and will be improved and updated regularly.

Concerning the database content, a major problem, in the treatment of archive data in landslide studies usually comes from the subjectivity and sensitivity of the individual sampler. This unavoidably influences the quality of the data. In order to reduce this heterogeneity and to standardize the data collection, the surveyed cases information has been formatted according to a census sheet of landslide dams proposed by Casagli and Ermini (1999). The sheet includes all the most important parameters of the landslide, the blockage, the dammed stream and the lake. It is divided in two parts. The first part is dedicated to the description of space and time characteristics of the landslide. The second part, dedicated to the dam and the hydraulic section affected by the landslide, allows a complete classification of the event, characterized using geomorphological, geotechnical and hydrological-hydraulic data. The census sheet represents one single event and its possible recorded reactivations are events in their own right that have to be recorded in different sheets. All the existing and new events were uniformed to this census sheet scheme which was afterwards translated to a relational geo-database structure.

As shown in Table 1, collected data were assembled in a single database with a simple and intuitive structure containing all the collected cases. The database is composed by 57 information fields easy to collect and measure even by people that are not landslide dam experts so as to maximize the probability of high accuracy data retrieval during future emergencies. Such approach has been chosen in order to privilege the usability and has significant advantages for a future usage in triage activity. In order to make the census as much objective as possible, the descriptive fields and the note field in the database are limited to a minimum and the fields with single or multiple constrained choices are favored.

The data in the database can be gathered into six main groups according to the type of information they provide:

1. Localization: in these fields all data about geographical position of the landslide (both the crown and the accumulation) and other information useful to its localization and identification are present. The unique Identification Number (ID) is used to univocally identify each landslide dam.

2. Consequences: containing a description of the consequences (damage to property or fatalities) of

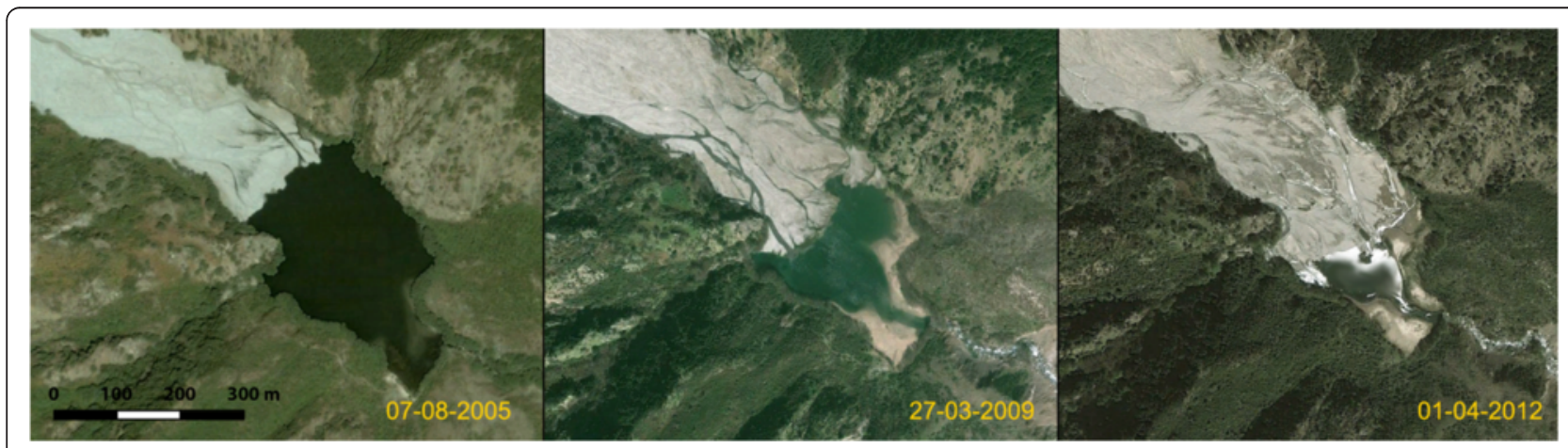

Fig. 3 Evolution from 2005 to 2012 of silting up of Costantino Lake (ID 97), Reggio Calabria, Southern Italy (pictures from GoogleEarth) 


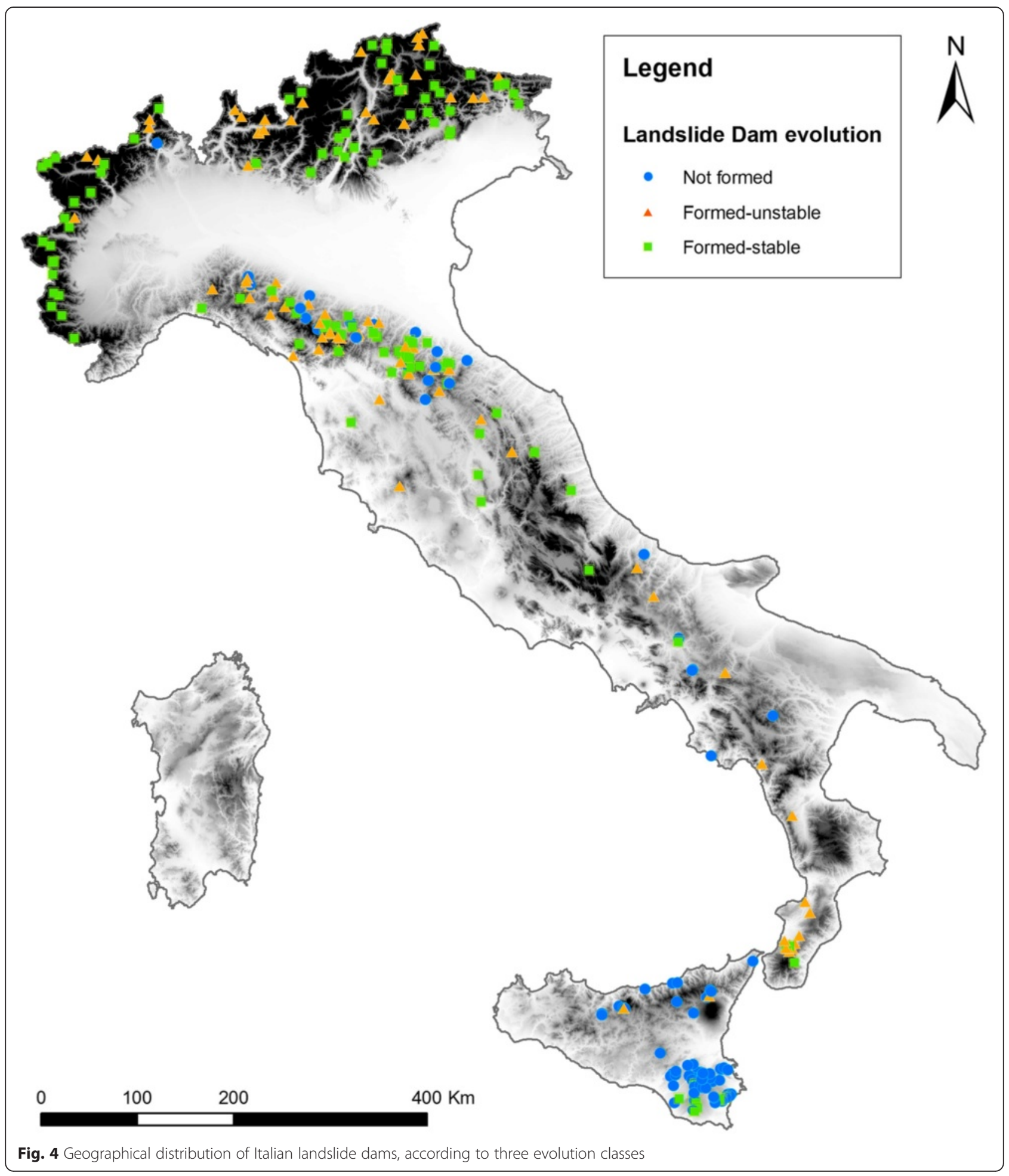

the landslide, the lake (upstream) and of the flood wave (downstream). In this section, the references to the data sources about the event are also listed.

3. Landslide: information useful to landslide characterization is listed here. Both general descriptive data (such as landslide material and trigger) and morphometric data are collected. The description of landslide type, movement, material, and water content follow the standards proposed by Cruden and Vernes (1996). A measurement of the landslide velocity has not been implemented due to the very low percentage of cases with 
Table 1 The information fields (grouped in six main groups) structuring the landslide dam database with used unit of measure and short description

\begin{tabular}{|c|c|c|c|}
\hline & Information & Unit & Description \\
\hline \multirow[t]{7}{*}{ Localization } & ID & [ ] & Unique Identification Number of the Landslide \\
\hline & Locality & text & Local name where damming occurred \\
\hline & Municipality & text & Italian Municipality where damming occurred \\
\hline & Province & text & Italian Province where damming occurred \\
\hline & Region & text & Italian Region where damming occurred \\
\hline & UTM E, N crown & [ ] & E and N Coordinate of the Landslide crown (WGS 1984-UTM, zone 32) \\
\hline & UTM E, N dam & [ ] & E and N Coordinate of the Landslide dam (WGS 1984-UTM, zone 32) \\
\hline \multirow[t]{5}{*}{ Consequences } & L.-damages & text & Direct Damages caused by the landslide \\
\hline & u-damages & text & Upstream Damages caused by the rising water \\
\hline & d-damages & text & Downstream Damages caused by the outburst flood \\
\hline & Bibliography & text & Bibliographic references about the event \\
\hline & Note & text & Additional note or information \\
\hline \multirow[t]{18}{*}{ Landslide } & Movement & text & Landslide movement classification (Cruden and Vernes, 1996) \\
\hline & Velocity & text & Velocity classification of the Landslide (Cruden and Vernes, 1996) \\
\hline & $v$ & {$[\mathrm{~m} / \mathrm{s}]$} & Velocity measure of the landslide (Cruden and Vernes, 1996) \\
\hline & Material & text & Landslide material classification (Cruden and Vernes, 1996) \\
\hline & Lithology & text & Lithology classification of the landslide \\
\hline & Water c. & text & Water Content classification of the landslide (Cruden and Vernes, 1996) \\
\hline & H L. & {$[\mathrm{m}]$} & Altitude difference between higher and lower part of the Landslide \\
\hline & a & {$\left[{ }^{\circ}\right]$} & Steepness of slope opposite to the Landslide \\
\hline & $\beta$ & {$\left[{ }^{\circ}\right]$} & Steepness of Landslide slope \\
\hline & LL.tot. & {$[\mathrm{m}]$} & Total length of the Landslide \\
\hline & LL.body & {$[\mathrm{m}]$} & Length of Landslide body \\
\hline & Wmax & {$[\mathrm{m}]$} & Maximum width of the Landslide \\
\hline & Wmin & {$[\mathrm{m}]$} & Minimum width of the Landslide \\
\hline & $D_{\text {rf }}$ & {$[\mathrm{m}]$} & Thickness of the Landslide \\
\hline & S L. & {$\left[\mathrm{m}^{2}\right]$} & Surface of the Landslide \\
\hline & V L. & {$\left[\mathrm{m}^{3}\right]$} & Volume of the Landslide \\
\hline & Trigger & text & Trigger mechanism of the landslide \\
\hline & Prev. activations & $\mathrm{dd} / \mathrm{mm} / \mathrm{yyyy}$ & Previous Activations of the Landslide before the damming event \\
\hline \multirow[t]{12}{*}{ DAM } & Date of damming & $\mathrm{dd} / \mathrm{mm} / \mathrm{yyyy}$ & Date Of Damming \\
\hline & Date of failure & $\mathrm{dd} / \mathrm{mm} / \mathrm{yyyy}$ & Date Of Failure of the dam (if any) \\
\hline & d type & ( & Classification of the dam (Costa and Schuster, 1988) \\
\hline & $L d$ & {$[\mathrm{~m}]$} & Length of the dam \\
\hline & $W d$ & {$[\mathrm{~m}]$} & Width of the dam \\
\hline & $\mathrm{Hd}$ & {$[\mathrm{m}]$} & Height of the dam \\
\hline & $S d$ & {$\left[\mathrm{~m}^{2}\right]$} & Surfece of the dam \\
\hline & $V d$ & {$\left[\mathrm{~m}^{3}\right]$} & Volume of the dam \\
\hline & $Q d$ & {$[\mathrm{~m}]$ a.s.l. } & Altitude of the spill way (above sea level) \\
\hline & d condition & text & Dam Condition \\
\hline & Evolution & text & Evolution of the landslide dam \\
\hline & Type of Failure & text & Dam failure mechanism (if any) \\
\hline Stream & Main Basin & text & Name of the main basin \\
\hline
\end{tabular}


Table 1 The information fields (grouped in six main groups) structuring the landslide dam database with used unit of measure and short description (Continued)

\begin{tabular}{|c|c|c|c|}
\hline & Dammed R. & text & Name of the dammed river \\
\hline & Wvalley & {$[\mathrm{m}]$} & Valley Width \\
\hline & Subt. S & {$\left[\mathrm{km}^{2}\right]$} & Surface of the basin subtended by the landslide dam \\
\hline & S & {$\left[{ }^{\circ}\right]$} & Steepness of river bed \\
\hline \multirow[t]{10}{*}{ Lake } & Lake name & text & Lake Name \\
\hline & L lake & {$[\mathrm{m}]$} & Length of the lake \\
\hline & W lake & {$[\mathrm{m}]$} & Width of the lake \\
\hline & D lake & {$[\mathrm{m}]$} & Depth of the lake \\
\hline & S lake & {$\left[\mathrm{m}^{2}\right]$} & Surface of the lake \\
\hline & V lake & {$\left[m^{3}\right]$} & Volume of the lake \\
\hline & Q lake & [m] a.s.l. & Lake altitude (metres above see level) \\
\hline & h of Lac.dep. & {$[\mathrm{m}]$} & Height of lacustrine deposits (if any) \\
\hline & Lake life time & text & Life time of the dam (hours, days, mounths, years, centuries) \\
\hline & Lake Condition & text & Lake Condition \\
\hline
\end{tabular}

Landslide dams database structure

information related to speed. However, an assessment of the order of magnitude of landslide velocity was possible thanks to the evaluation of the effects of the landslide in the formulation of Cruden and Varnes (1996). These authors established a relationship between different levels of damage, produced by the landslide, with different speed thresholds of the mass movement. In this way, they identified seven classes of damage and the same number of speed ranges, with a logical scheme similar to the Mercalli scale formulation for the earthquakes intensity.

4. Dam: in these fields both descriptive and morphometric information on dam characterization are reported. In addition, information about the dam condition and event evolution are provided. According to the geomorphological classification proposed by Costa and Schuster (1988), landslide dams were classified in six types:

- Type I: small landslides compared to the riverbed, which did not reach the opposite side of the valley. In this case there is no dam in fact.

- Type II: landslides that cross the valley from side to side and realize dams.

- Type III: big landslides that reach the opposite side of the valley, moving upstream and downstream, and realize dams. They may run up the opposite slope.

- Type IV: dams formed by two contemporaneous mass movements from the opposite valley sides. Both the two landslides are numbered with an unique Identification Number (ID), distinguished with ",1" and ",2" after it.
- Type V: dams produced by multiple lobes of the same landslide.

- Type VI: cases in which the sliding surface passes below the river bed, rising it.

For the Dam Condition ten option are available (Casagli and Ermini, 1999):

- Partial blockage: if the obstruction of the riverbed caused by the landslide is not complete (Type I of the Costa and Schuster (1988) classification) without the formation of an impoundment and a dam, but with the reduction of riverbed section.

- Toe erosion: if the landslide's foot is eroded by the stream.

- Artificially cut/stabilized: the landslide dam is cut/ stabilized thanks the human work.

- Slightly/moderately/strongly cut: the dam body is eroded in different extent, with small, medium and big intensity.

- Not cut: the dam has not been cut yet and it is fully intact.

- Breached/Partly breached: the dam completely/ partly collapsed.

The dams were classified in three classes according to their Evolution from their formation until now:

- Not formed: cases of partial damming of a stream, with just a reduction of the riverbed section. The formation of an upstream lake basin did not occur. The river deviation or the landslide toe erosion can be the further consequences. 
- Formed-unstable: the landslide leads to the formation of dam and a lake basin, which remained for a variable span of time (from hours to centuries) until the general collapse of the dam, often caused by external contributing factors (e.g. earthquakes). The failure of the blockage dismantles the dam body and leads to the release of a catastrophic flooding wave due the emptying of the impounded water, with high human danger. The dam body ruins are often barely recognizable. This class has been bestowed also when the human intervention has strongly influenced the dam evolution (e.g. with an artificial cut or stabilization) to prevent possible dangerous consequences.

- Formed-stable: the landslide caused the complete blockage of the stream and the consequent formation of a lake basin. The dam is in a global stability and in dynamic balance from its formation. It is preserved until now, or it extinguished for filling. In some cases, the dam has suffered overtopping episodes with partial erosion, even the complete incision of the dam body, but no general collapse or catastrophic flooding wave occurred.

There are three possible Type of Failure mechanisms (Costa and Schuster, 1988):

- Overtopping.

- Piping.

- Slope failure.

5. River: containing the main parameters of the stream, the watershed area above the dam and the valley itself, as its width.

6. Lake: containing the main morphometric parameters of the impoundment, if formed, and details on its evolution.

For the Lake Condition eleven options are available (Casagli and Ermini, 1999):

- Not formed (generic)/for erosion/for infiltration/for deviation: the lake did not form; is possible to specify the cause (for erosion, infiltration or deviation).

- Existing/existing partly filled: the lake still exist/but can be partly filled.

- Disappeared (generic)/for man-made influence/for spillway erosion/for filling/for dam collapse: the lake no longer exists; is possible to specify the cause (man-made influence, spillway erosion, filling or dam collapse).

\section{Utility}

According to many authors (Swanson et al.; 1986; Canuti et al., 1998; Ermini and Casagli, 2003; Dal Sasso et al., 2014) landslide dam behavior can be forecasted through geomorphological indexes. Said indexes are comprised of variables identifying the landslide (or the dam) and the river involved. These tools have given encouraging results, showing great potential as assessment and forecasting tools. The knowledge of these events is, however, far from complete, since there are many contributing factors in determining their development and behavior over time.

In order to develop reliable tools to assess the formation and stability of landslide dams, it is fundamental to acquire large data archives covering as many areas as possible collected with consistent methodologies and with standardized information quality.

\section{Discussion}

In Italy landslide dams, like landslides in general, are a highly widespread phenomena. In Fig. 5, landslide dams occurred during the last thousand years in Italy dated through bibliographic data or with research on historical evidence are shown. In the figure a significant increase can be observed from the beginning of the XVIII century, in the period known in literature as the "Little Ice Age" (between the mid-XVI and mid-XIX century). During this period, strong advances of the glaciers fronts and episodes of freezing of the main streams occurred. However, this climatic oscillation can only partially explain the increase in the landslide frequency. Canuti et al. (2004) partly attributes the general increase of landslides during the last five centuries also to a peak in clear-cutting of forests in the same period. Moreover, the historical documents useful to identify a blockage events begin to be more frequent, widespread and best preserved to this day only in recent centuries, probably due to the spread of printing in the fifteenth and sixteenth centuries. Diffusion of information in the twentieth century, in fact, led to gather information on nearly 90 landslide dams in the last century.

From the distribution map of landslide dams in Fig. 4, at first glance, it is immediately possible to notice a higher concentration of cases in the Alps and the northern Apennines than in the Southern part of Italy. The distribution of dams collected in Italy is obviously affected by the number and distribution of studies conducted so far and also by the morphological evidences that each event left on the territory. For this reason we are reasonably sure that we are aware of most of the sizable cases occurred in historical times in Italy, but also that many others, possibly of minor importance, were not detected. However, there are some inconsistencies, in terms of number of existing cases between one area and another that can be due to two reasons. 


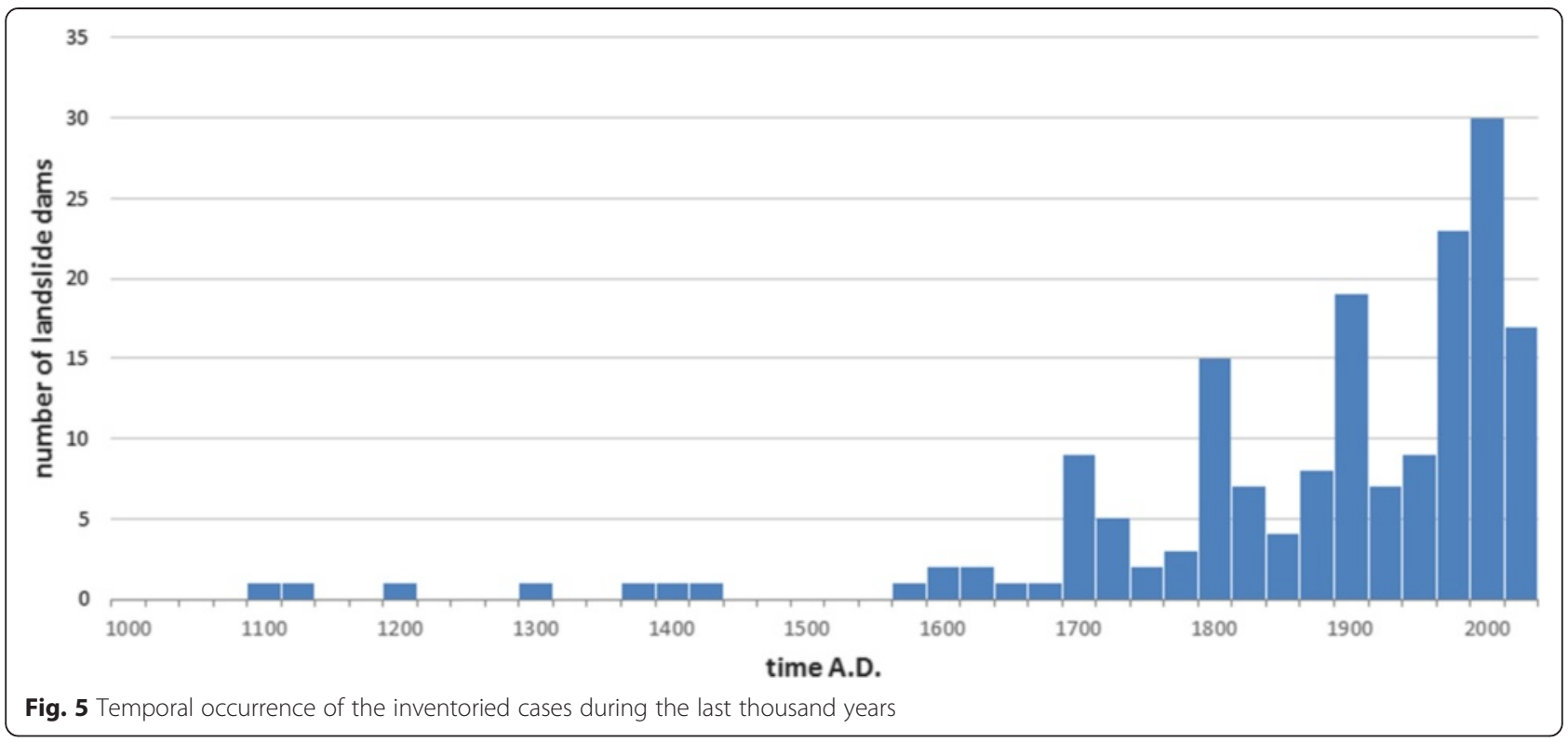

Firstly, the different morphological and hydrogeological characteristics of the affected areas, which control the formation of the dam and constrain the geometry of the obstruction. Secondly, the quality and quantity of references founded, which can be much different for different cases. Except for Sicily, in fact, the number of sources about events located in the Southern Apennines is lower as compared to the Northern part of Italy and sometimes it was not even possible to identify the exact location of the described landslide dam.

The more a bibliographical record is related to an event far in the past (and/or of small size) the lower the accuracy of the data and the morphologic evidence is preserved. A study case that clearly illustrates this possibility is the seismic event that affected large part of Southern Italy in February 5, 1783, with maximum intensity in the Calabria Region. The earthquake caused more than $31^{\circ} 000$ victims and huge damages. Countless were the landslides triggered by the event, including several oversized which destroyed entire villages dragging them downstream. Rivers were diverted or dammed, with the formation of at least 215 lakes (Fig. 6), as reported by Ruberti (1787) and Vivenzio (1788). Because the lack of clear evidences in the current morphology and since most of the lakes were located along counterslopes within landslide bodies, it was possible to identify only a small part of the dams on the Calabrian territory.

The same difficulty generally occurs to identify Type I dams. According to the morphological classification proposed by Costa and Schuster (1988), these are the smaller type of landslide dam, compared to the valley size, that cannot reach the opposite slope but just reduce the riverbed width. Indeed landslides that fail to completely block a river valley generally have a small volume (compared to the river discharge) and their morphologic evidence is erased in a short time by the erosive capacity of the watercourse. Most of these landslide dams, because of their small volume, produces no social impacts on the territory and therefore it is not reported from any source. Therefore, we can assume that this kind of landslide partial damming are much more frequent than known.

As shown in Fig. 7, the lowest volume measured in the database was about $10^{4} \mathrm{~m}^{3}$ and this lower boundary is fully into the typical range of Type I dams. Furthermore, most part of landslide dams with unknown volume belong to Type I. It can be assumed that at least a part of these dams had a small volume, even lower than $10^{4} \mathrm{~m}^{3}$. So, in average, this order of magnitude can be considered as the minimum landslide volume that can cause any kind of detectable effect on a riverbed.

The severity of the consequences of a landslide dam comes directly from its evolution. The three evolution classes (not formed, formed-unstable, formed-stable), are a useful classification tool to distinguish the wide range of possible dams, grouping them into sets with similar characteristics and behavior.

The result of the division of the collected cases into evolutionary classes does not show a clear dominance of one class over the others. The formed-stable dams are the most frequent with $39 \%$ of the cases, closely followed by the not formed with $33 \%$ and then by the formed-unstable with $28 \%$.

According to the landslide dam classification proposed by Costa and Schuster (1988) Fig. 8a) the most common class of Italian dams is the type II, representing $41 \%$ of the total amount. Following, there are landslide dams of type I with $26 \%$ and of type III with $24 \%$. 


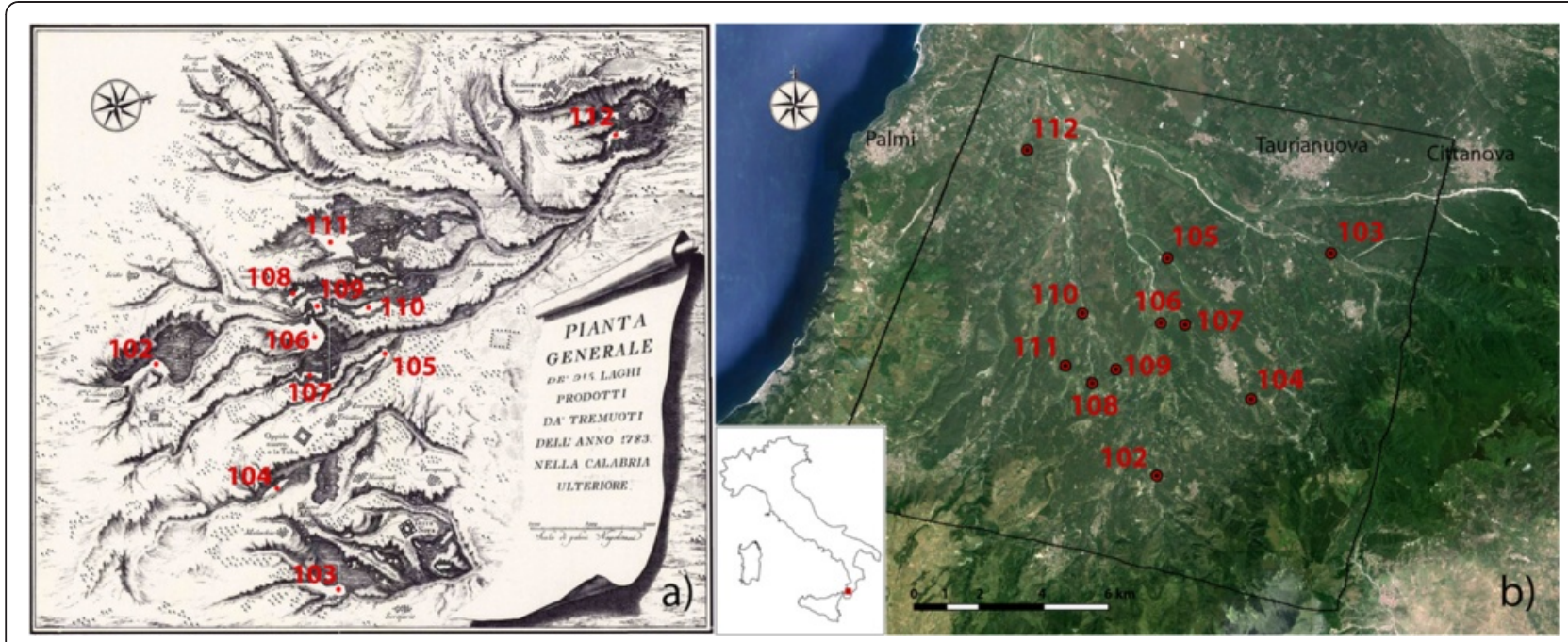

Fig. 6 a Map of the 215 lakes formed by the earthquake of 1783 in Calabria, Southern Italy (from Vivenzio, 1788 modified); b Real position of the greater lakes. 102: S. Cristina; 103: Marro; 104: Birbo; 105: De' Preti; 106: Cumi; 107: Tricuccio; 108: Cucco; 109: Speziale; 110: Coluce; 111: S. Bruno; 112: Tofilo

Much less frequent are the blockages of type IV and VI, both with about $4 \%$. In Italy dams of type $\mathrm{V}$ were not distinguished from the others so type $\mathrm{V}$ was not considered in the statistics. While the most frequent type of blockage, represented by type II landslide dam, is in agreement with that observed by Casagli and Ermini (1999) in the Northern Apennines, the percentage about type I is much higher (27\% against $19 \%$ for Casagli and Ermini, 1999 and 11 \% for Costa and Schuster, 1988). Type II and type I of landslide dams in whole Italy overcome even those of type III, that in Casagli and Ermini (1999) and Costa and Schuster (1988) were the second most frequent blockage type.

As regards their evolution, Fig. 8b) shows that the notformed class represents $100 \%$ of the dams of type I and between 5 and $25 \%$ of types II, III and VI, while they were not found among type IV.

The formed-stable blockages are the most representative class among the landslide dams of type II and III with $55-60 \%$ of the cases, while among the landslide dams of type IV and VI the formed-unstable blockages are the most frequent with about $50 \%$ and $35 \%$ respectively.

The histogram of Fig. 9 shows the type of landslide movement (Cruden and Varnes, 1996) included in the database. The term "complex" is referred to the style of a landslide characterized by two or more main movements combined in time or in space.

Five main types of movement are most widespread in Italy, even though outside of the particular category of landslides that cause damming. The landslides classified as

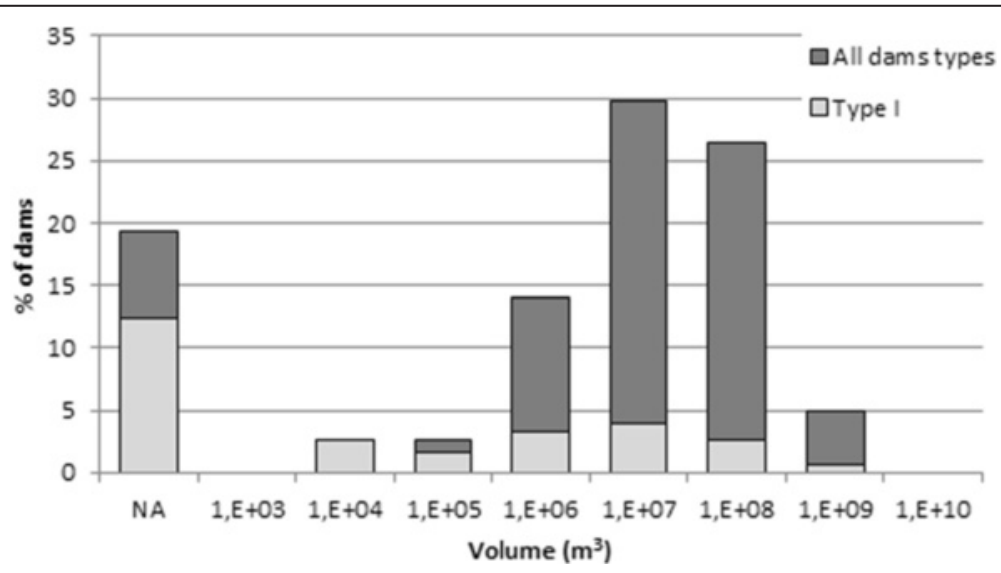

Fig. 7 Volumes distribution of landslide dams collected in Italy. The part of them represented by Type I dams (according to the classification proposed by Costa and Schuster, 1988) are highlighted in blue. (NA = Not Available) 

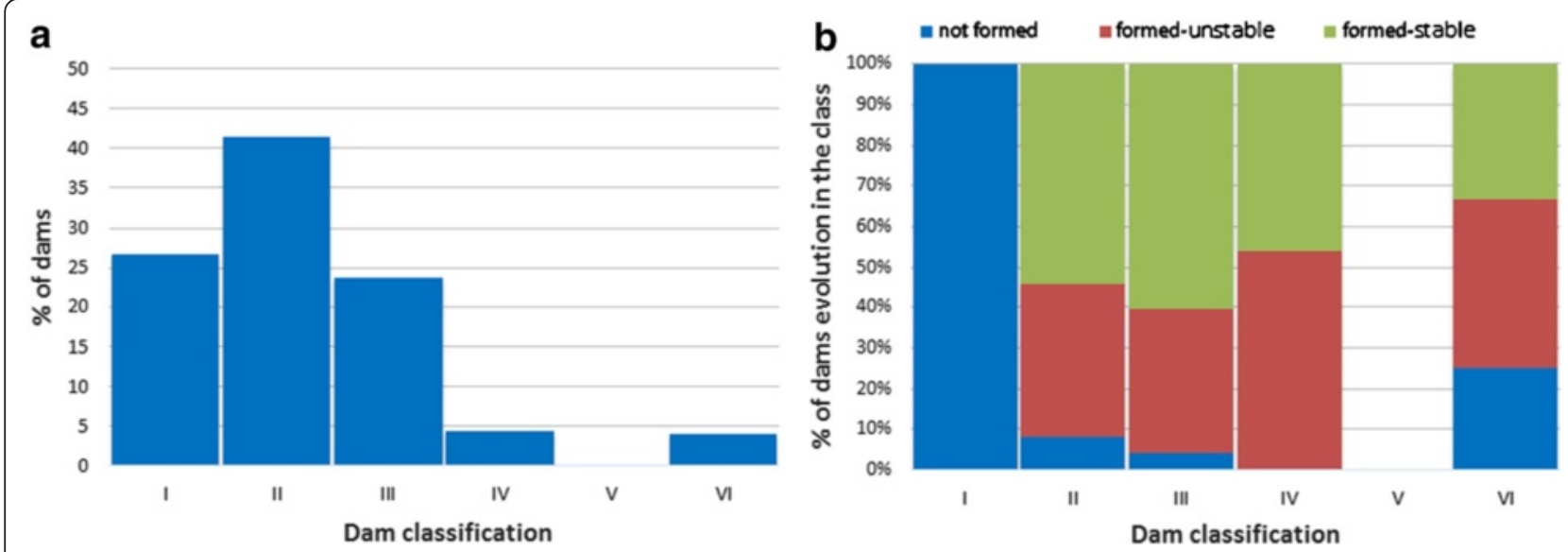

Fig. 8 Classification of landslide dams in Italy a according to Costa and Schuster (1988) b and their evolution classes distribution

complex are the most common with 99 checked cases and usually are the result of a first translational and/or rotational slide movement of debris and/or rock, that evolve in a second movement classified as a mud or debris flow. Very common throughout the territory are also individual rotational (with 87 cases) and translational slides (48 cases). Blockages of river courses rarely occur by flows, falls or topples, because the volume of involved material is usually small and no visible traces of the landslide remain. Between the landslides that originated the obstruction of a stream bed there are no reported lateral spread cases in Italy.

From the point of view of the evolution, most part of the landslides classified as fall (63\%) and complex $(50 \%)$ resulted in formed-stable dams and just a fraction of these landslides $(10 \%$ for falls and $15 \%$ for complex landslides) did not produce a complete obstruction. Instead, a small part of the landslides classified as flows formed a dam stable until now (only $14 \%$ ), while the majority of formed dams were stable only for a short period of time (44\%) or not formed at all (41\%). Slides, translational or rotational, have a completely different evolutionary behavior. The rotational slide are almost equally distributed in not formed, formed-unstable and formed-stable, and most part of the translational movements seem not to be able to build a complete damming (56\%). When the damming is complete, though, it is often stable (37\%). The higher stability of fall and complex landslides compared to flows is probably due (Canuti et al., 1998) to the usual bigger volume and the internal geotechnical properties of the fall and complex landslides materials.

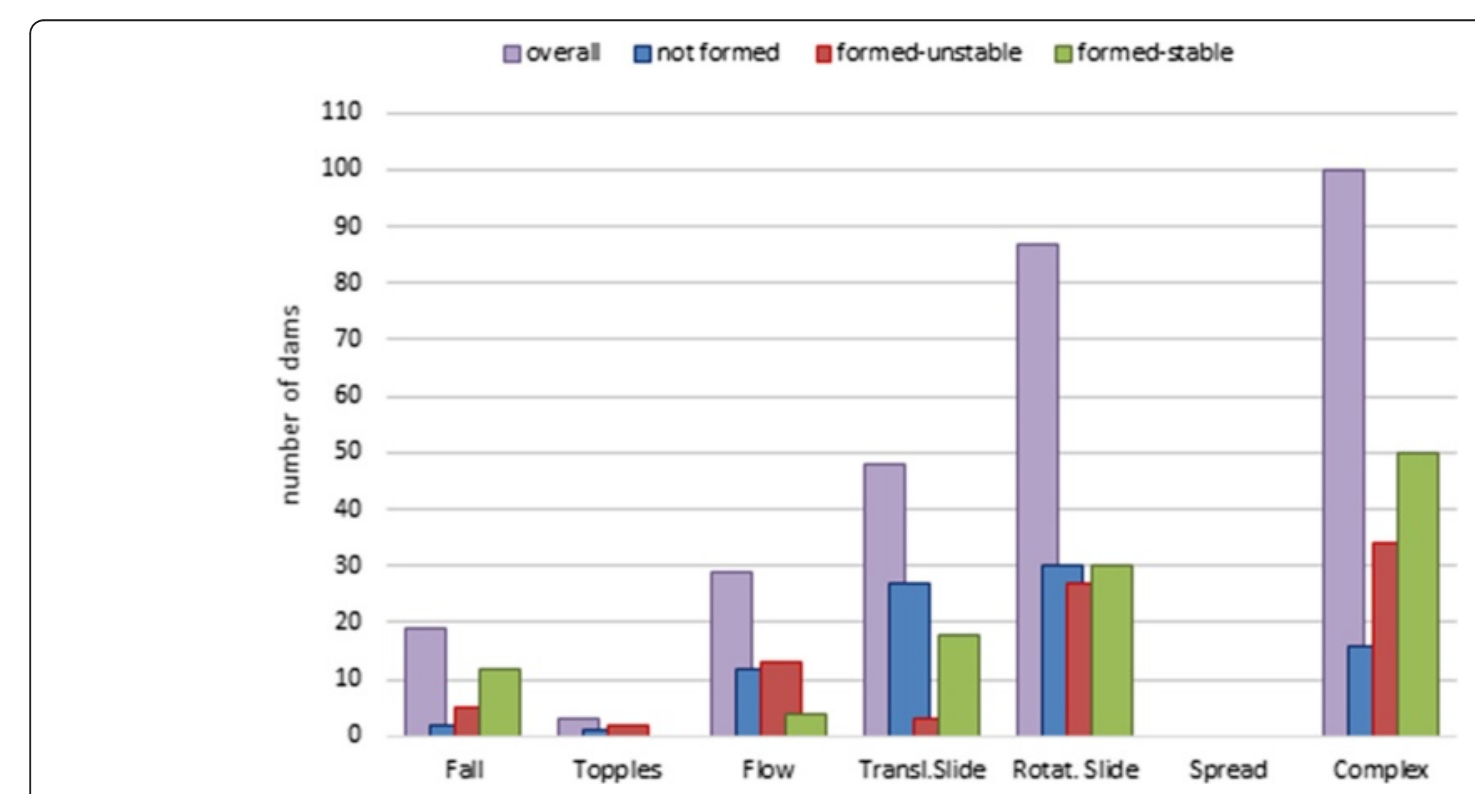

Fig. 9 Types of landslide movement compared with the evolution of the dam in Italy 
An important characteristic for purposes of civil protection and for the assessment of the damage caused by landslide dams is the durability of the dam body over time, especially in the short term. Most landslide dams fail by overtopping or piping shortly after their formation (Costa and Schuster, 1988; Ermini and Casagli, 2003), typically in conjunction with the first serious hydraulic emergency faced by the dam.

Figure 10 shows the dam longevity curve constructed using all the available data. A large part of landslide dams (about $65 \%$ ) fail by overtopping or piping within one month of their formation, in agreement with what reported by Costa and Schuster (1991) and Ermini (2000), while about $20 \%$ of the total are stable for over a year and almost $10 \%$ for over 10 years. A statistics on this kind of time behavior for landslide dams is particularly important since it is known, from the analysis of past cases, that there are dams that remain stable for decades and then suddenly collapse when it was believed that they were stable. These events often cause extensive damage because all precautions and alert conditions were removed, as happened for the case of Kummersee lake (ID 118), in Northern Italy (Pirocchi, 1991), or for the Matthieu lake in Dominica, West Indies (James and De Graff, 2012), which collapsed respectively 15 and 14 years after the formation. The former reached the city of Merano located $25 \mathrm{~km}$ downstream, causing 400 casualties, with a wave of mud and debris, while the latter did not result in fatalities or injuries because it occurred in the middle of the night in a rural area with no inhabitants, despite significant property and infrastructure losses.
In order to investigate the formation of a natural dam and its stability, the following triggering causes for landslide dam were recognized in the Italian database:

- Snow fall or melting.

- Fluvial erosion.

- Heavy rainfall.

- Anthropic causes.

- Earthquakes.

Although the triggering causes were unknown or uncertain in 130 cases of the database, just over half of the remaining cases $(52 \%)$ were provoked by seismic events and approximately another third (33.5 \%) by heavy rainfall events. The remaining part is shared by fluvial erosion with $10.4 \%$, snow fall or melting with $2.9 \%$ and anthropic causes with $1.2 \%$.

The geographical distribution of Italian landslide dams according to their main triggering causes seems to reflect the heterogeneous distribution of geological environments. If the national territory is divided from North to South in Alps, Northern Apennines and Southern Apennines, as shown in Fig. 11a) almost all of the dams caused by seismic events are located in the Southern Apennines. In fact about $77 \%$ of the 104 landslide dams surveyed in Southern Italy with known trigger are caused by high magnitude earthquakes (Fig. 11b). However, this statistics is heavily influenced by the catastrophic seismic event of 1783 with 13 cases.

In the Northern Apennines and along the Alps, instead, the most frequent triggering cause for landslide dams is

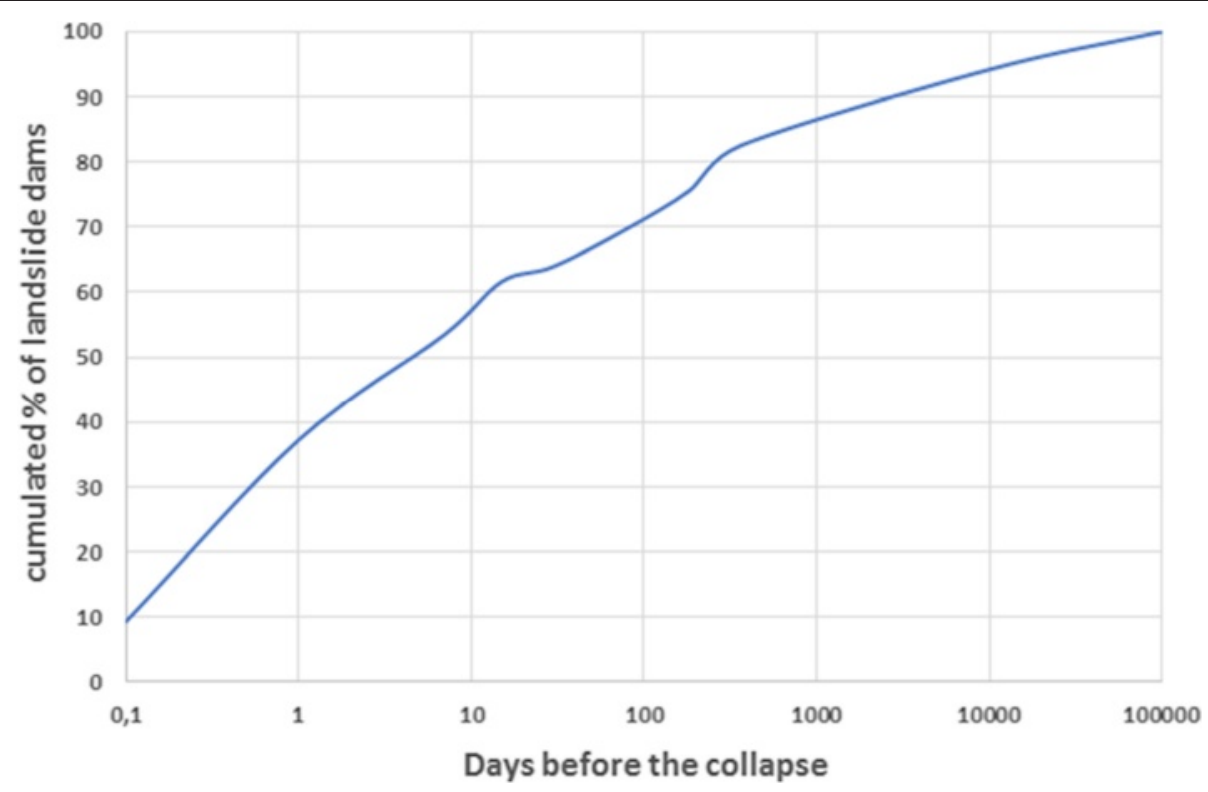

Fig. 10 Survival time before the failure of landslide dams 


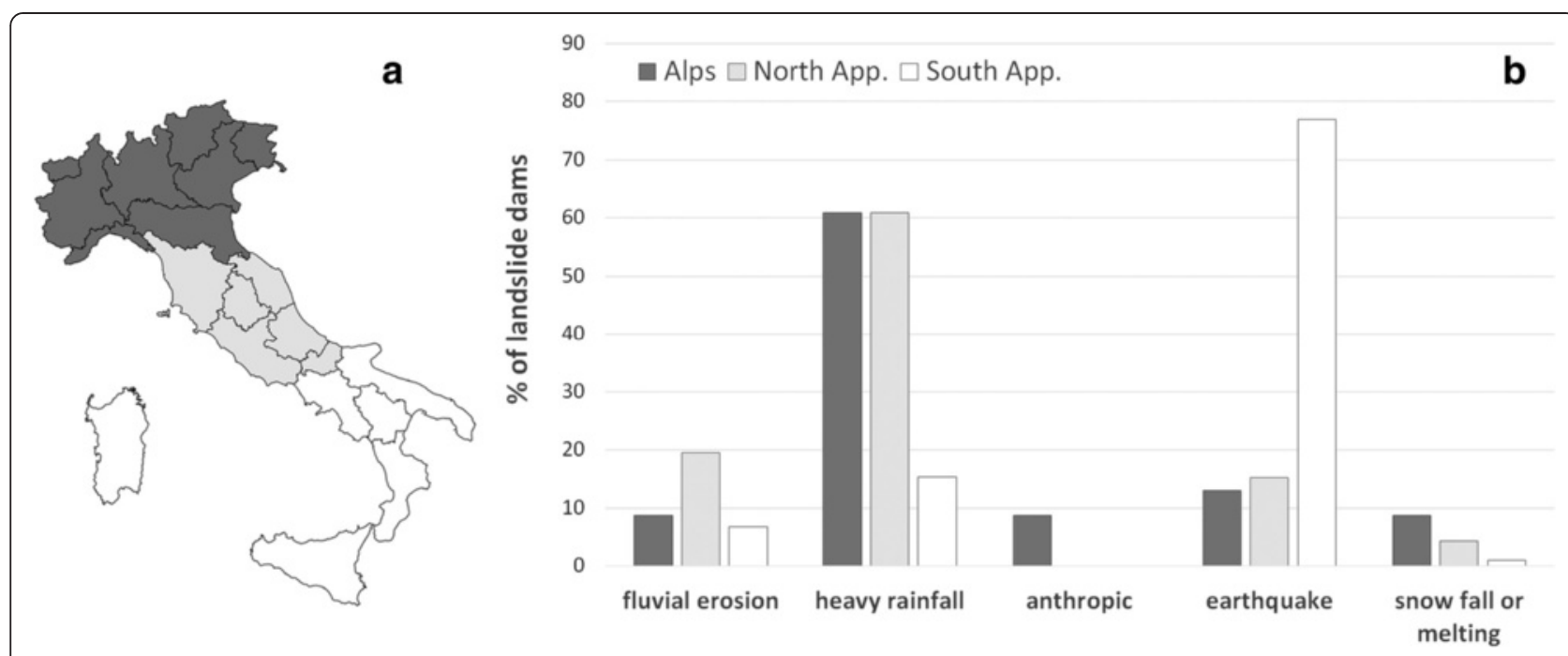

Fig. 11 a Division of Italian territory in Alps, Northern Apennines and Southern Apennines regions; b Distribution in the three Italian regions of the triggers of movements that formed a landslide dam

the intense rainfall, with $61 \%$ and $59 \%$ respectively. This difference with respect to the Southern Apennines highlights how Italy is representative of a large diversity of climatic and geological environments but it is also due to a few large earthquake events that have recently hit that part of Italy. Alps are glaciated areas with high relief energy and high gradients. The Northern Apennines are characterized by a highly variable morphology and several high intensity rainfall areas, while the Southern Apennines are areas with less rainy climate and tectonically active, characterized by an higher seismic activity.

It is also important to describe in details and to classify landslide triggering factors to check if they control somehow the blockages evolution.
Figure 12 shows the evolution classes of the inventoried landslide dams, according to the landslide triggers. The unstable dams are clearly prevailing between landslides caused by intense rainfall events and snowmelt, reaching $53 \%$ and $60 \%$ of the singles categories respectively. Those caused by river erosion are equally distributed between not formed and formed-unstable, with $39 \%$ each and $22 \%$ of formed-stable. In Italy landslides caused by earthquakes, usually (58 \% of cases), do not produce dams because, often, they involve small volumes of material. However, during earthquakes of higher magnitude, the volume of triggered landslides may be much greater so that $27 \%$ of dams formed are formed-stable, compared to $15 \%$ of the formed-unstable. This is the

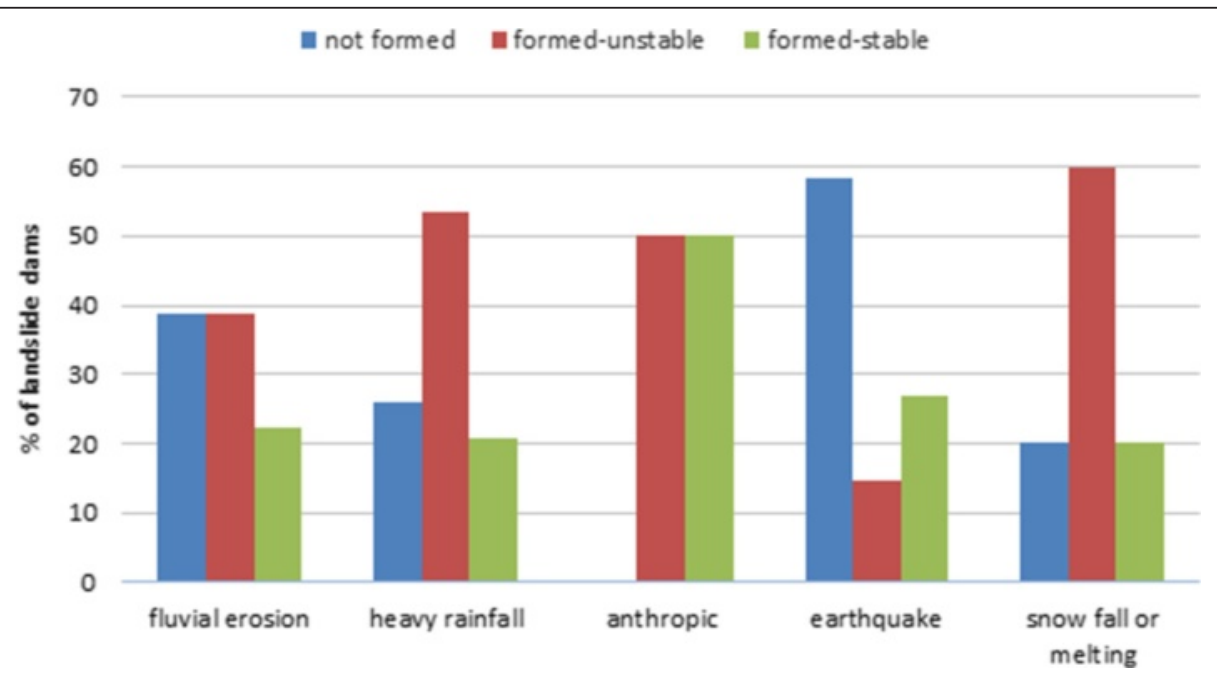

Fig. 12 Evolution of the inventoried landslide dams, according to the cause that triggered movement 
only category where the number of formed-stable dams is greater than formed-unstable dams.

\section{Conclusions}

Landslide dams are the result of the complex interaction between river and slope dynamics, not yet fully understood. In order to provide the base to develop specific forecasting tools to assess the landslide dam formation and evolution, the main aim of this research was to compile a large data archive, collected with a consistent and standardized methodology.

The research started updating previous studies on the same topic in smaller areas (Pirocchi, 1991; Ermini, 2000; Pacino, 2002) and integrating them through cartographic and aerial photo interpretation and a careful literature review. This data set represents the first systematic national inventory of landslide dams in Italy.

The data were gathered in a database, comprising of 300 records, with a simple format to privilege usability and future implementation. It is composed of 57 easyto-collect-and-measure information fields, representing the most important morphological parameters and information about landslide dams.

Many of the cases are from historical events, often related to big seismic events (mainly in Southern Italy) or deglaciation phenomena (mostly in Northern Italy). In some cases, the lack of historical documents and direct information made it difficult to reconstruct the event, especially where the morphological evidence of the dam are not clear anymore. Available documents provide direct information for historical events, often describing catastrophic events as they really happened, but sometimes with fictional elements.

\section{Availability and requirements}

- Available database:

- Any restrictions to use by non-academics: none.

\section{Additional file}

Additional file 1: Landslide Dams DataBase. Description of data: archive of 300 Italian landslide dams described trough 57 information fields useful for events characterization. Both descriptive data and morphometric data are present. (PDF 4903 kb)

\section{Competing interests}

The authors declare that they have no competing interests.

\section{Authors' contributions}

CTS carried out the investigations, collected the data and drafted the manuscript; FC participated in the arrangement of the structure and correction of the manuscript and in the discussion and conclusion of the research; NC gave suggestion in the research structure and the analysis and provided advices to the study. All the authors read and approved the final manuscript.

\section{Acknowledgements}

We acknowledge Leonardo Ermini for his advices during the start of the research sharing his experience in the data collecting and geomorphological analysis and precious knowledge about landslide dams.

Received: 13 May 2015 Accepted: 4 August 2015

Published online: 14 August 2015

\section{References}

Almagià R (1907) Studi Geografici sopra le frane in Italia. Mem Soc Geogr It 13, Vol XIII:342

Boccia A (1804) Viaggio ai monti di Parma. Libreria Aurea, Parma

Bonnard C (2011) Technical and Human Aspects of Historic Rockslide Dammed Lakes and Landslide dam Breaches. In: Natural and Artificial Rockslide Dams. Springer, Heidelberg, pp 101-122

Canuti P, Casagli N, Ermini L (1998) Inventory of Landslide Dams in the Northern Apennine as a Model for Induced Flood Hazard Forecasting. In: Andah K (ed) Managing Hydro-Geological Disasters in a Vulnerable Environment. CNR-GNDCI and UNESCO IHP, Perugia, pp 189-202

Canuti P, Casagli N, Ermini L, Fanti R, Farina P (2004) Landslide activity as a geoindicator in Italy: significance and new perspectives from remote sensing. Environ Geol 45(7):907-919

Carotta A (1997) Le nostre radici: Brancafora. La Serenissima, Vicenza, p 333

Casagli N, Ermini L (1999) Geomorphic analysis of landslide dams in the Northern Apennine. Trans J.jn Geomorphol 20(3):219-249

Casagli N, lotti A, Tarchiani U (1995) Caratteri geomorfologici e geotecnici della frana di S. Benedetto Val di Sambro (BO). Proceeding of II Incontro Internazionale di Giovani Ricercatori in Geologia Applicata, Politecnico di Torino, Torino, 11-13 October 1995

Cencetti C, De Rosa P, Fredduzzi A (2011) Cellular automata model: an application to landslide dam of "Le Mottacce" (Tuscany, Central Italy). Ital J Eng Geol Env 1:45-60, Special Issue 2011

Coico P, Calcaterra D, De Pippo T, Guida D (2013) A Preliminary Perspective on Landslide Dams of Campania Region, Italy. In: Landslide Science and Practice. Springer, Heidelberg, pp 83-90

Costa JE, Schuster RL (1988) The formation and failure of natural dams. Geol Soc Am Bull 100(7):1054-1068

Costa JE, Schuster RL (1991) Documented historical landslide dams from around the world. US Geol Surv 91-239:486, Open-File Report

Cruden DM, Varnes DJ (1996) Landslides: Investigation and Mitigation. In: Turner AK, Shuster RL (eds) Transportation Research Board, Special Report 247., pp 36-75

Dal Sasso SF, Sole A, Pascale S, Sdao F, Bateman Pinzòn A, Medina V (2014) Assessment methodology for the prediction of landslide dam hazard. Nat Hazards Earth Syst Sci 14:557-567

Ermini L (2000) Elaborazione di un modello per la precisione dell'evoluzione di sbarramenti fluviali causati da frane, unpublished. Unpublished PhD thesis, University of Florence, p 159.

Ermini L, Casagli N (2003) Prediction of the behavior of landslide dams using a geomorphological dimensionless index. Earth Surf Proc Land 28(1):31-47

Evans SE (1984) The 1880 landslide dam on Thompson River near Ashcroft, British Columbia. Geological Survey of Canada, part A, 655-658

Evans SE (1986) Landslide Damming in the Cordillera of Western Canada. In: Schuster RL (ed) Landslide Dams: Processes, Risk, and Mitigation. Proceeding of a session sponsored by the Geotechnical Engineering Division of the American Society of Civil Engineers in conjunction with the ASCE Convention, American Society of Civil Engineers Geotechnical Special Publication, 3, Seattle, 7 April 1986

Fan X, Tang CX, van Westen CJ, Alkema D (2012a) Simulating dam-breach flood scenarios of the Tangjiashan landslide dam induced by the Wenchuan Earthquake. Natl Hazards Earth Syst Sci 12(10):3031-3044

Fan X, van Westen CJ, Korup O, Gorum T, Xu Q, Dai F, Huang R, Wang G (2012b) Transient water and sediment storage of the decaying landslide dams induced by the 2008 Wenchuan earthquake, China. Geomorphology 171:58-68

Fan X, van Westen CJ, Xu Q, Gorum T, Dai F (2012c) Analysis of landslide dams induced by the 2008 Wenchuan earthquake. J Asian Earth Sci 57:25-37

Irmler R, Daut G, Mäusbacher R (2006) A debris flow calendar derived from sediments of lake Lago di Braies (N. Italy). Geomorphology 77(1):69-78

James A, De Graff JV (2012) The draining of Matthieu landslide-dam lake, Dominica West Indies. Landslides 9(4):529-537

Korup O (2004) Geomorphometric characteristics of New Zealand landslide dams. Eng Geol 73(1):13-35 
Lee KL, Duncan JM (1975) Landslide of April 25, 1974 on the Mantaro River, Peru. Natl Acad Sci, Washington DC

Mercanti L (1859) Poche parole su i lavori di prosciugamento da eseguirsi a Pieve S. Stefano di Luigi Mercanti, Tip Bellotti, Arezzo

Nishizawa Y, Chiba T (1979) Landslide dam in the Sai River and floodplains. Geomorphology 4:459-486

Pacino V (2002) Censimento degli sbarramenti da frana in Sicilia, unpublished. Unpublished Bachelor's degree thesis, University of Florence, p 211

Peng M, Zhang LM (2012) Breaching parameters of landslide dams. Landslides 9(1):13-31 Pirocchi A (1991) Laghi di sbarramento per frana nelle Alpi: tipologia ed evoluzione. Unpublished PhD thesis, University of Pavia, p 155

Pirocchi A (1992) Laghi di sbarramento per frana nelle Alpi: tipologia ed evoluzione. Atti I convegno Nazionale Giovani Ricercatori in Geologia Applicata 93, 128-136.

Roberti F (1787). Memoria su i lavori per lo disseccamento dé laghi i Calabria Ulteriore eseguiti sotto la direzione dell'Ingegnere Militare D. Ferdinando Ruberti, No editor.

Savelli D, Nesci O, Troiani F, Dignani A, Teodori S (2012) Geomorphological map of the Montelago area (North Marche Apennines, central Italy): constrains for two relict lakes. J Maps 8(1):113-119

Savelli D, Troiani F, Brugiapaglia E, Calderoni G, Cavitolo P, Dignani A (2013) The landslide-dammed paleolake of montelago (north marche apennines, italy): geomorphological evolution and paleoenvironmental outlines. Geogr Fis Din Quat 36(2):267-287

Schuster RL (1985) Landslide Dams in the Western United States. Proceedings of IVth Int. Conf. and Field Workshop on Landslides, Tokyo, pp 411-418

Soldati M, Tosatti G (1993) Case histories of lake-forming landslides in the Dragone Valley (Northern Apennines, Italy). In: 7th International Conference and Field Workshop on Landslides. AA Balkema, Rotterdam, 28 August-15 September 1993 Swanson FJ, Oyagi N, Tominaga M (1986) Landslide Dams in Japan. In: Schuster RL (ed) Landslide Dams: Processes, Risk, and Mitigation. Proceeding of a session sponsored by the Geotechnical Engineering Division of the American Society of Civil Engineers in conjunction with the ASCE Convention, American Society of Civil Engineers Geotechnical Special Publication, 3, Seattle, 7 April 1986

Vivenzio G (1788) Istoria de' tremuoti avvenuti nella Provincia della Calabria Ulteriore, e nella città di Messina nell'Anno 1783. E di quanto nella Calabria fu fatto per lo suo risorgimento fino al 1787. Precedute da una Teoria ed Istoria generale dei tremuoti, Illa edizione, Stamperia Reale, 2 voll., Napoli

\section{Submit your manuscript to a SpringerOpen ${ }^{\circ}$ journal and benefit from:}

- Convenient online submission

- Rigorous peer review

- Immediate publication on acceptance

- Open access: articles freely available online

- High visibility within the field

- Retaining the copyright to your article

Submit your next manuscript at $\boldsymbol{\wedge}$ springeropen.com 